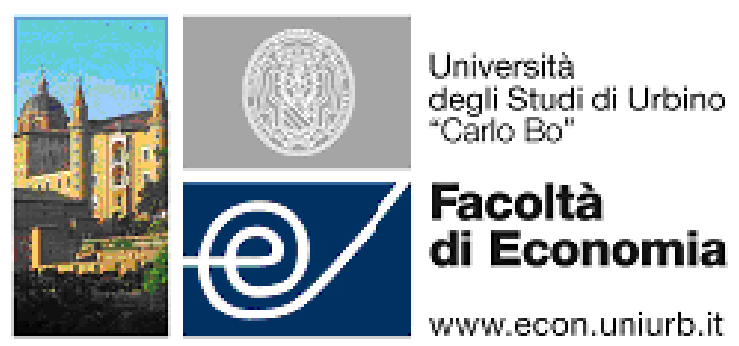

WP-EMS

Working Papers Series in Economics, Mathematics and Statistics

\title{
"HETEROGENEITY AND DISTANCE. SOME PROPOSITIONS ON HOW DIFFERENCES ACROSS REGIONS, FIRMS AND FUNCTIONS AFFECT THE ROLE OF DISTANCE IN FDI LOCATION DECISIONS"
}

- Davide Castellani (University of Perugia, Italy)

- Giulio Giangaspero (Sapienza University of Rome, Italy)

- Antonello Zanfei (University of Urbino, Italy) 


\title{
Heterogeneity and distance. Some propositions on how differences across regions, firms and functions affect the role of distance in FDI location decisions
}

Davide Castellani (University of Perugia, Italy)

Giulio Giangaspero (Sapienza University of Rome, Italy)

Antonello Zanfei (University of Urbino, Italy)

\begin{abstract}
The idea that distance may hinder cross-border economic activities has a long tradition in both international trade and international business studies. And the need to consider distance as a multifaceted concept including both spatial and institutional features has also been increasingly acknowledged in the literature. In this paper we argue that the complexities of distance factors and their impact on FDIs can be best appreciated when considered across regions, across firms and across functions. We present some developments in extant literature that account for heterogeneity in each of these three directions, and draw some implications for the analysis of FDIs location decisions.
\end{abstract}

JEL: F23, O33

Keywords: FDIs, Multinationals, Distance, Heterogeneity

Parole chiave: IDE, Multinazionali, Distanza, Eterogeneità 


\section{Introduction}

The idea that distance may hinder cross-border economic activities has a long tradition in both international trade and international business studies. And the need to consider distance as a multifaceted concept including both spatial and institutional features has also been increasingly acknowledged in the literature.

Geographic distance has been broadly used as a proxy for uncertainty related to the liabilities of foreignness, and for transportation costs associated to doing business in remote locations. This has been the case with gravity like models, starting from the seminal contribution of Tinbergen (1962), that have been subsequently extended to the analysis of FDIs (Bergstrand and Egger, 2007; Blonigen, Davies and Head, 2003; Carr, Markusen and Markus, 2001; Egger and Pfaffermayr, 2004; Kleinert and Toubal, 2010).

Non-geographic distance factors - including cultural, social, normative and economic disparities - have received increasing attention when explaining bilateral cross-border transactions. Starting from the conceptualization proposed by Johanson and Vahlne (1977), management studies have focused on psychic and cultural distances as determinants of the location of FDIs, using various measures as those proposed by Hofstede (1980) and Kogut and Singh (1988), with subsequent developments and extensions (Dow and Kuranaratna, 2006, Berry et al., 2010). International trade literature has also acknowledged that social and institutional factors need to be included in theoretical and empirical models to better capture the wide variety of obstacles to international transactions that have long been associated with a single "rough measure" like geographic distance (Beckerman, 1956, Linnemann, 1966; Geraci and Prewo, 1977; Casella and Rauch, 2003, Guiso et al., 2009).

The increasing and generalised attention to this variegated set of factors is reflected in the proliferation of terms by means of which "non geographic" barriers to internationalization are identified and measured, including "unfamiliarity" (Grossman, 1996; Huang, 2007), "perceptual distance" (Ellis, 2008), "psychic distance stimuli" (Dow and Kuranaratna, 2006; Håkanson and Ambos, 2010), and "institutional distance" (Abdi and Aulakh, 2012; Dunning and Lundan, 2008; Solomon and $\mathrm{Wu}, 2012$; Xu, Pan and Beamish, 2004) ${ }^{1}$.

In this paper we argue that the complexities of distance factors and their impact on FDIs can be best appreciated when considered across regions, across firms and across functions.

Evaluating distance factors across regions marks a departure from traditional approaches to the analysis of FDI location decisions. Studies in both Trade and International Business (IB) literature have initially adopted aggregate levels of analysis, focusing on distance factors between pairs of countries, largely disregarding the variety of territories within nations. More recently, several studies have suggested that there are wide sub-national variations within countries that should be accounted for when we investigate where firms will locate their subsidiaries (see inter alia, Mudambi and Beugelsdjik, 2013; Shenkar, 2001). As we shall see, the presence of cross-

\footnotetext{
${ }^{1}$ For a comprehensive review of the various types of distance to which scholars have devoted their attention, it may be useful to refer to Em's (2011) empirical study based on a lexicographic and content analysis on the last twenty years of publications of the Journal of International Business Studies: she finds that "the types of distance are most of the time poorly defined, misunderstood and mixed up" and proposes definitions of psychic, cultural, cognitive and institutional distances. For the purpose of this paper, a general way of defining "non geographic" distance factors, which we adopt hereafter, is the one adopted by Dunning (2009, p.24): "the concept of "institutional distance" appears to be a general and comprehensive way of identifying transnational differences in terms of formal and informal rules, incentive structures, enforcement mechanisms, and voluntary behavioural initiatives which will ultimately affect firms choices".
} 
regional differences has important implications on the analysis of distance factors and of their impact on FDI location decisions.

Moreover, distance factors reflects differences across firms. Once again the literature has paid relatively little attention to this aspect. In fact, most studies assume that firms of a certain country could be expected to have a homogenous perception of how distant a foreign location is, and that distance would affect FDI decisions of all firms from a given home location in the same way. While this assumption helps simplify the analysis of FDI decisions, it largely contradicts the generalised view that firms' international strategies may develop in dissimilar ways. As Smith, Dowling and Rose (2011) suggest, managers will react to similar distance factors in different ways, according to their personal history and characteristics, so that in the end firms' internationalization decisions will be heterogeneous even within the same industry and across firms belonging to the same country. Moreover, firms differ in terms of their past history of internationalisation (IettoGillies, 2001), extension of their internal and external networks (Zanfei 2000), and hence experience of foreign locations. This can be expected to affect the direction and intensity of their further location strategies.

Furthermore, extant literature has only recently acknowledged the importance of distinguishing the differentiated impact of distance across functions, with different activities carried out by the same firm being affected by distinct (combinations and intensities of) distance factors. While this view has been implicitly adopted by some studies dealing with the complexities of distance factors in international distance (e.g. Berry et al., 2010), and may well affect the way FDI promotion and attraction policies are designed (OECD, 2011), very limited systematic research has been conducted from this perspective. Along this line, a recent study by Castellani, Jimenez and Zanfei (2013) has shown that the location of R\&D labs is affected more by institutional distance factors than by geographical distance. In fact, the available set for locations of certain types of activities - for example, high-tech research - may be more limited, thus leaving less choice to firms on whether to locate R\&D facilities in nearby or in more remote locations (Castellani, Jimenez and Zanfei, 2013; von Zedtwitz and Gassman, 2002). Hence what really matters for the location R\&D activities, unlike the location of production activities, is not so much the extent of geographic separation, but the ease of communication, which is in turn more affected by cultural and social diversity.

With all these premises in mind, in the following pages we present some developments in extant literature that either provide evidence for the heterogeneous effect of distance factors within countries/across regions, across firms and across functions, or suggest that it could be relevant to investigate this issue further. In the concluding section of this paper we discuss some methodological issues raised by this finer analysis and speculate on implications for future research.

\section{Heterogeneity across regions}

In the OLI paradigm (Dunning, 1977), firms' foreign activities are driven by the interaction of three sets of advantages: ownership (O) advantages stemming from the proprietary (or de facto) control of assets and resources, location (L) advantages deriving from resources and institutions in the host economy, and internalisation (I) advantages related to the ability to exploit and recombine internally ownership and location specific assets. While this framework is general enough to accommodate all factors influencing FDI decisions, analyses of location specific advantages have long focused on the country level, largely disregarding sub-national factors, excluding, for example, agglomeration processes, urbanisation or local networks. These factors are now increasingly receiving the attention of IB scholars, especially at the intersection with economic geography (Iammarino and McCann, 2013; Crescenzi, Pietrobelli and Rabellotti, 2012). Although the literature 
on FDI determinants at the sub-national level is extensive ${ }^{2}$, the role of distance between home and host locations has been rather neglected in such studies. Thus, our first proposition is that distance across sub-national contexts matters and should be better explored when considering FDI location decisions.

In fact, both geographic and institutional distance factors may be affected by heterogeneity within countries and across regions. On the one hand, spatial distance is of course dissimilar between different regions within pairs of large countries: for example, consider how the number of miles separating (whichever place in) two regions in China and Brazil may vary depending on where these regions are located within these two quasi-continental sized countries. From this perspective, Shenkar (2001) had already pointed to the unrealistic assumption of subnational spatial homogeneity. On the other hand, the role of intra-national diversity may be even stronger when institutional factors are considered. Focussing on cultural factors, Stottinger and Schlegelmilch (1998) suggest that individual perceptions of country distance are quite likely to be different from aggregate national cultural distances based on measures such as Hofstede's scale. It is a matter of fact that there is a huge variance, in terms of cultures, institutions and natural resource endowment, within countries. For instance, it seems difficult to state that ethnic/linguistic communities inside a country have no substantial implications in creating cultural diversity and variations. In a similar vein, the so called 'mask of homogeneity' (Tung and Verbeke, 2010), which implies that cultural differences between regions of the same country are negligible, is quite misleading especially when we consider large and variegated countries. Focussing on institutional factors, it is very common that provincial governments across a single country offer different investment incentives (UNCTAD, 2006). Regarding China in particular, some recent studies focus on FDIs inflows and provincial location factors, among which geographic distance of each province from the main sea port of the region, is taken into account in the empirical test on the determinants of provincial FDI inflows (Chen, 2011; Sethi, Judge and Sun, 2011).

These findings also combine with the observation that many territories can share more institutional similarities with regions located across national borders, rather than with regions of the same country. Basile et al. (2008) show that the degree of similarity perceived by MNEs locating manufacturing plants in Europe is higher across - rather than within - national borders. From this perspective the distance that matters is not so much between countries but between aggregates of regions exhibiting some similarities in terms of their socio-economic characteristics, although they might belong to different countries. And it is not only a matter of territorial contiguity: in many capital towns across different countries of the world, consumption patterns and ways of life may be considered analogous, whereas remarkable variations can be observed between metropolitan areas and more dispersed zones of every single country (Goerzen et al., 2013). As highlighted by Rugman, Verbeke and Nguyen (2013), in the presence of high distance (whichever its nature and however it may be measured), firms will choose to locate in cosmopolitan large cities, where already established business communities and practices will create agglomeration economies, create some sort of institutional proximity, and compensate for the costs associated with spatial separation.

Economic geographers have looked more deeply at the local dimension of firms and their linkages with territories, and the literature on the relation between firms and the concepts of place,

\footnotetext{
${ }^{2}$ See, among others, Basile et al. (2006, 2008), Cantwell and Piscitello, (2005), Crescenzi et al. (2013), Defever (2006, 2008, 2012), Head and Mayer (2004), for studies of the location of MNEs in European regions, as well as studies on the location of multinationals within individual countries in Europe, such as France (Crozet et al., 2004), Italy (Bronzini, 2007; Mudambi and Navarra, 2003; Mariotti and Piscitello, 1995), Romania (Hilber and Voicu, 2010), Spain (Pelegrin and Bolancé, 2008), UK (Dimitropoulou, McCann and Burke, 2013). There are also various studies of location of MNEs across states in the U.S. (Head et al., 1999; Hennart and Park, 1994; Halvorsen, 2012; Nachum, 2000), and in other parts of the world, such as the study of Meyer and Nguyen (2005) on sub-national institutions in Vietnam.
} 
space and organization is vast ${ }^{3}$. Thus, as Mudambi and Beugelsdijk (2013, p.414) have argued, there is the need for " $(. .$.$) incorporating relevant insights on subnational spatial variation from EG$ [Economic Geography], into the modern theory of the MNE (...)". For example, EG scholars in particular apply a distinction between border - which creates a geographical break - and distance which can be measured in a continuum (Mudambi and Beugelsdijk, 2013). While borders identify a mere separation between territorial entities, distance involves the degree of separation between such territorial entities. Moreover, borders and distance factors should be considered at the finest possible level of geographic disaggregation: national, regional, provincial and city levels. This implies a deeper and more comprehensive analysis of how national and subnational factors combine and impact on FDI decisions, going beyond the consideration of "international border effects" (McCallum 1995) to include sub-national differences as determinants of trade (Anderson and van Wincoop 2003; Head and Meyer, 2002; Hillberry and Hummels 2003, 2008; Coughlin and Novy, 2013; Wolf 2000). In Management studies there has also been a growing attention to the issue of disentangling border effects and spatial distance factors. For example, Singh and Marx (2013), find that, on average, country and state borders significantly constrain knowledge diffusion - captured in terms of citations between random pairs of patents - even after accounting for metropolitan collocation and different measures of spatial separation. They suggest that this finding reflects the importance of institutional diversity not only across countries but also across subnational regions. (Singh and Marx, 2013, p.2076).

Another path along which EG research provides useful insights for IB scholars concerns the concept of proximity (Boschma, 2005; Broekel and Boschma, 2012), that may be considered as specular to the concept of distance, more diffused in the IB field. Similar to what has happened with the debate on distance in IB and International Trade studies, proximity too has been acknowledged as a multifaceted construct. Scholars have identified different proximity dimensions between firms that have been applied to study several phenomena, including the relation between geographical proximity and innovation (Maskell and Malmberg, 1999; Boschma, 2005), the relation between organizational proximity (the existence of intra-regional and interregional networks) and firm performance (Oerlemans and Meeus 2005), technological proximity and patents (Benner and Waldfogel, 2008), social proximity and knowledge spillovers (Breschi and Lissoni, 2003). The efforts that this stream of literature devotes to "penetrate the black box of geographical space" (Maskell and Malmberg, 1999, p.90) and its attention to spatial clustering and/or dispersion of firms offer complementary hints and tools to IB scholars.

\section{Heterogeneity across firms}

The impact of distance factors does not only vary within countries and across territories: institutional and geographic distances are firm specific, too. This level of heterogeneity across firms was largely disregarded in Hofstede's work on cross-cultural differences (1980), in a large fraction of studies on psychic distance ${ }^{4}$, and in management studies based on the institutional theory ${ }^{5}$. The implicit assumption in Hofstede's framework and subsequent studies was that all firms originating from any given countries could be expected to have the same propensity to avoid uncertainty and to deal with unfamiliar contexts. Indeed this approach contradicts much of the emphasis in extant

\footnotetext{
${ }^{3}$ For a recent discussion on the current links between international trade theory, economic geography and strategy and international business see: Beugelsdjik, McCann and Mudambi, 2010; Iammarino and McCann, 2013.

${ }^{4}$ Starting from the Uppsala school development of the concept (Johanson and Vahlne, 1977) to the studies of Dow and Karunaratna (2006); Dow and Ferencikova (2010); Dow and Larimo (2009/2011) and Håkanson and Ambos (2010).

${ }^{5}$ Institutional theories applied to study of MNEs assume that a firm may be situated in multiple institutional fields and operate under multiple institutional pressures. Some of these pressures are local in origin and others are national, leading to "collective action" typical of all organizations in a nation (Xu and Shenkar, 2002).
} 
literature on the role of firm heterogeneity in international trade and international business ${ }^{6}$ : firms are different and there is no reason to believe that they would react in the same way to geographical and institutional distance, when taking their foreign location decisions. First, international business studies have emphasised that managers may have a different perception of distance according to their culture and personal history. Second, industrial organization and management studies as well as international trade literature have emphasised that firms differ in terms of their organizational structure and international experience, which may also moderate the role of distance factors.

With respect to the first line of argument, Smith, Dowling and Rose (2011) developed an analytical framework that combines the national and the firm level. They go beyond Dow and colleagues $^{7}$ and Håkanson and Ambos (2010), whose studies on psychic distance emphasize objective national stimuli or antecedents which impact on managers' internationalization choices. Smith et al. (2011) instead focus on how these objective factors impact and identify the mechanisms underlying the transition from the national level, where the stimuli have to be found, to the firm level, that is where firms' internationalization choices are made. They develop a tripartite level of analysis. First, at the national level they consider the exogenous factors (stimuli) analysed by Dow and Karunaratna (2006), which are likely to differentiate internationalisation behaviour from one country to another; these factors are supposed to increase the uncertainty associated with foreign markets. Second, they consider the individual level determinants, which are all the factors related to managers' personal history and traits ${ }^{8}$. The national and individual levels are linked by information flows ranging from multiple sources (e.g. media, networks of contacts, internet), and the information received will be influenced by, and cognitively processed through, the individuals' characteristics and traits. Finally, Smith et al. (2011) consider the firm-level: the individual manager's perception combine with country-level stimuli, and jointly determine firms' distinctive patterns of internationalisation. In our view, the authors' innovative contribution is to cast light on the mechanisms underlying the connections between macro factors and firms' choices, so that we may understand better how national objective factors will impact on firms' strategies. The proposed analytical framework is a first step towards dealing with heterogeneity across firms, and how this dimension impacts on the relationship between distance and foreign location decisions. In fact, it allows us to account for differences across firms even when they face the same national level factors (in terms of both geographic and institutional distance) and are endowed with the same information sets about a foreign market: this is because, at the individual level, managers will absorb stimuli in different ways, they will react to them according to their personal history and characteristics, so that in the end their firms' international strategies may develop in dissimilar ways.

However, Smith et al. (2011) do not fully capture the interaction between national level stimuli, individual level characteristics and firms' structural and strategic characteristics. In fact, not only managers' history and cultural traits (in combination with objective national-level factors) impact on internationalisation strategies. A firm's structure of incentives, competencies and routines also determines its internationalization strategy.

\footnotetext{
${ }^{6}$ Firm level heterogeneity has been acknowledged in international trade literature wherein intra-industry differences in productivity are associated with different degrees of internationalisation (inter alia: Helpman et al., 2004; Yeaple, 2009). These models formalise an old idea that has emerged early in the economics of multinational enterprises, dating back to Hymer (1960) and Dunning (1970) who have emphasised that it is only firms characterised by superior technology that will eventually be able to overcome the extra-costs of doing business abroad

${ }^{7}$ We are referring to the following contributions: Dow and Karunaratna (2006); Dow and Ferencikova (2010); Dow and Larimo (2009/2011).

${ }^{8}$ At the individual level the authors distinguish between objective and subjective characteristics of an individual; in the first category fall determinants associated to his/her personal history (international experience, cultural background, education, foreign language skills) whereas in the subjective category fall characteristics related to the individual's personality traits (conservative nature, risk tolerance, proneness to change, flexibility).
} 
An extensive literature has analysed how the structural characteristics of MNEs impact on FDI strategies MNEs develop internal procedures and organizational cultures - that we may call corporate culture (Heskett and Kotter, 1992) - which will in turn have consequences inter alia on the role of distance. In fact, even if corporate culture will necessarily reflect the norms, codes of conduct and social characteristics of the home country, being active in many different institutional contexts will influence the organizational culture of each individual MNE. This in turn may reduce the institutional distance between an MNE and a host location.

In this perspective, international experience ${ }^{9}$ can be an important mediating factor in the relationship between distance and MNEs' location choices. For example, firm $a$ from country $i$ that has subsidiaries in a country $j$ might be considered "closer" to that host country compared to another firm $b$ from the same home country $i$ that has not yet internationalized in host country $j$. In other words, previous internationalization activities increases a company's acquaintance with local norms, rules and codes of conduct, hence reducing the costs of dealing with unfamiliar locations. Inter alia, it has been shown that MNE's prior experience in a region increases the likelihood of that region being selected by the MNE for offshore manufacturing and R\&D projects (Basile et al., 2008; Demirbag and Glaister, 2010). The evidence on how firms' international experience moderates the impact of distance on internationalisation strategies is rather scanty and mixed. This may be due to a double set of problems: on the one hand, international experience is per se a multifaceted concept whose implications on MNEs' strategies need be further explored, as observed inter alia by Castellani and Zanfei (2004), and Dow and Larimo (2011). On the other hand, different measures of distance may affect results. Dow and Larimo (2011) test determinants of entry mode of a sample of manufacturing Nordic firms controlling for a wide set of psychic distance variables, and find that general internationalization knowledge is strongly associated with greenfield investments while cluster-specific experience is associated with acquisitions ${ }^{10}$. A possible interpretation of these results is that international experience may moderate the impact of distance on cross border investment decisions. And this moderating effect will significantly differ according to the nature of internationalization experience - i.e. whether generic or specific to a given geographic area or sector.

Furthermore, Hutzschenreuter et al. (2011) argue that the impact of international experience on firm's behaviours is subject to dynamic adjustments. These authors focus their attention on the different impacts of experience over time, finding that firstly, a firm with a higher geographic spread (and associated extant cultural diversity) will have to deal with higher dynamic adjustment costs and, secondly, high cultural diversity determines systematic environmental and organizational complexity for the MNE, so that "[...] the extant cultural diversity characterizing the portfolio of local contexts within which the MNE operates has a negative effect on the rate of its further international expansion" (Hutzschenreuter et al., 2011, p.321).

De Beule, Elia and Piscitello (2013) analyse entry mode strategies and combine two factors of heterogeneity across firms, such as the "origin effect", by comparing MNEs from Emerging Markets (EMNEs) with MNEs from advanced countries, and a firm's previous local experience. They find that when the institutional distance between home and host country is high EMNEs will choose a high degree of control, while MNEs from advanced countries will opt for the opposite strategy and will look for a partner. Instead, they don't find any significant effect of previous experience on the choice of minority participation vs. full acquisitions. This finding might be

\footnotetext{
${ }^{9}$ See, for example, Castellani and Zanfei (2004) in the case of multinational firms in the chemical and electronics industries, or the review on international experience in IB studies by Clarke, Tamaschke and Liesch (2013).

${ }^{10}$ Castellani and Zanfei (2004) further distinguish: a specific experience that multinational enterprises accumulate with reference to individual countries or regions, a variety experience that refers to the geographic dispersion of international activities and, finally, internationalisation experience stemming from a firm's overall involvement in foreign markets, regardless of the number of countries in which there is a firm's FDI and the depth of the involvement in every location.
} 
influenced by the fact that their measure of experience is rather rough (a dummy variable which takes value 1 if a firm has already undertaken a previous investment in the host country) and might not fully capture the diversity across firms in this respect.

One might take a broader view on international experience, and suggest that both internal and external networks developed by MNEs may affect the role of distance in location decisions ${ }^{11}$. Even if two firms have their headquarters in the same locations, they will generally have different webs of foreign subsidiaries which are in turn embedded in different networks of relationships with indigenous parties, and will hence have different experience of local contexts and will perceive, and deal with, distance in a different way. In other words, the extension of the system of relations, both in geographical and institutional terms, impacts on the way firms deal with foreign locations. For example, Appold (1995) shows that when manufacturing firms are included in more collaborative networks created by their supplier and sub-contractors, with whom they can co-operate at the design and technical stages of the production, they are able to overcome larger distance in order to serve their customers. As the author posits it: despite the logistic difficulties associated with greater distance, firms with extensive networks are able to win customers over competitor firms that are located closer to these customers. Hence, the impact of both geographic and institutional distance on firms embedded in co-operative networks is lower.

In addition, we should consider another characteristic of a firm's network that is, how intense relations are between the firm's home base and its network abroad ${ }^{12}$. It has been frequently argued that the degree of control of a foreign subsidiary impacts on the knowledge of the foreign market that a firm may access and acquire: higher commitment entry modes may ensure that a larger amount of information in terms of demand characteristics, institutional factors, and local knowledge will accrue to the home country than in the case of lower commitment entry modes (Johanson and Vahlne, 1990; Yeoh, 2004). From this perspective, a fully-owned subsidiary might well be considered "closer" to a foreign location than a contractual agreement with a third party, so that a network composed of a number of high controlled subsidiaries in a certain location may reduce the perception of distance more than a network composed of subsidiaries with a lower commitment.

Hence, one could venture saying that what really matters is the distance between networks (internal and external to the MNE) and between nodes within networks. Moreover the institutional and structural characteristics of the networks to which the nodes belong also play a role in FDI location decisions.

\section{Heterogeneity across firms' functions}

Having discussed the consequences of heterogeneity across regions and across firms, let us now devote our attention to the heterogeneity within firms. Previous research has shown that the determinants of the location choice impact differently depending on the activity within each firm, so that the impact of distance can vary according to the type of activity being internationalised. Von Zedtwitz and Gassmann (2002) argue that the quest for technical know-how and expertise available in only a few centres-of-excellence around the world impacts on the location of research activities, while proximity to other corporate activities (e.g. manufacturing) and proximity to local customers drive the location of development activities. Defever (2006) explores the co-location of services and

\footnotetext{
${ }^{11}$ This line of argument has connections with the analyses of the "double network" structure of multinationals. This term identifies the combination of "internal networks" of affiliates and "external networks" of relationships with other parties, including suppliers, customers, competitors and institutions active in the different contexts in which MNEs are embedded. It has been shown that the development of such networks affects MNE's innovative activities as well as their propensity to absorb and diffuse knowledge in foreign contexts (Zanfei 2000, Castellani and Zanfei 2006).

${ }^{12}$ We have found in Clarke, Tamaschke and Liesch (2013) an important cue in a similar discussion on the intensity dimension of the foreign investment, applied to the study of international experience of a firm.
} 
other corporate functions, and their interactions with country location advantages, that are peculiar according to which function is internationalized.

Focussing on the aspects related to geographic distance, transportation costs have a lower impact on the transfer of weightless goods as compared to other activities. This implies that geographic distance should hinder the offshoring of some tasks and business activities more than others. Trefler (2005) and Lewin, Massini and Peeters (2009) focus on service offshoring and show that firms' locating a service activity in a foreign country search primarily for highly-skilled white collars, so that personnel's expertise and education are far more important than labour and transportation costs - that are usually the main motivations of manufacturing localization. Thus, the fact that a foreign location is offering skilled personnel and good ICT infrastructure overcomes the difficulties associated to the geographic distance of this location from the home base. In other words, firms locating service activities abroad may perceive that the distance of a location is not a hindrance to internationalisation with the same degree as a firm locating manufacturing activities abroad may do. In partial contradiction to that, Head, Meyer and Ries (2009) find that geographic distance has a negative and significant effect on offshoring of services (associated mainly to delivery costs), albeit declining over time.

However, it is not only geographic distance that plays a different role according to the nature of business activities. It is the mix of distance factors that may make the difference. Berry, Guillén and Zhou (2010) devote a big effort to the conceptualizing and developing a set of indicators that account for the multi-dimensionality of distance, and examine how each of the dimensions they consider has a different impact on MNEs choices to locate manufacturing and distribution activities. Using an institutional approach to cross-national distance they define nine dimensions related to economic, financial, political, administrative, cultural, demographic, and knowledge factors; they also add measures related to connectedness between country pairs, such as international tourism expenditure and Internet transactions and, finally, they consider geographic distance as a further control. They then test their model in a study on market entry and find that the effect of political distance (which relates to differences in strength of institutional checks and balances, to the transparency of decision making, and to the influence exerted by different stakeholders and lobbies) is negative on cross-border manufacturing, whereas it is positive on distribution activities, while demographic distance (which relates to fundamental characteristics of the population of countries that may affect consumer behaviour and other market-related processes of interest to firms, such as life expectancy, birth rate, age distribution of the population) is significant only for distribution subsidiaries ${ }^{13}$. The authors do not offer any sound explanations for these differences in impact. Nevertheless their study has the merit of highlighting that different facets of distance have a distinct impact on the international location of firms' activities.

More research has been devoted to explaining how distance affects international location of R\&D and knowledge intensive activities. Belderbos, Leten and Suzuki (2011) measure cross-border patent citations as an indicator of the ease of communication and collaboration, and find that geographic distance does not hinder the international knowledge transfer while sharing a common language explains more the location choice of this activity. Muralidaran and Phatak (1999) and Ambos and Ambos (2011) have studied the determinants of foreign R\&D, but a major limitation of both studies is the use of only one synthetic indicator (the Kogut-Singh index) for non-geographical distance. Athukorala and Kohpaiboon (2010) investigate R\&D intensity of foreign affiliates of USbased multinationals over the years 1990-2004 and find no significant impact of geographic distance in their study. Py and Hatem (2009) examine location choices concerning 737 R\&D

\footnotetext{
${ }^{13}$ Our mind may go again to a suggestion taken from economic geographers, related to the distinction between border and distance. Referring to Berry, Guillén and Zhou's (2010) distance dimensions, we may argue that political distance changes abruptly when there is a national border, whereas demographic distance may be measured as a continuous measure, depending on which level of analysis we take into account (national, regional, or city level).
} 
centres, which were established in Europe over the years 2002-2006, as part of a wider research covering also FDIs in other functional areas. They find that geographic distance has a negative effect, while language commonality has a positive impact on R\&D establishment. Dachs and Pyka (2010), using EPO data for the years 2000-2005, find that geographic distance is negatively correlated with the number of foreign patents obtained, while language commonality positively affects cross-border inventive activity. Picci (2010) uses a broader range of indicators of cultural and social proximity along with more traditional measures of geographical distance and language commonality as determinants of international patenting activities, and finds that geographic distance has a negative effect on bilateral knowledge transfers across countries, while other measures of cultural and social proximity exert a positive and significant effect. Castellani, Jimenez and Zanfei (2013), using a sample of over 6,000 bilateral investments of firms from 58 countries, show that R\&D location decisions are positively affected by institutional proximity and find that the latter has a higher impact than in the case of manufacturing activities, which are instead more affected by geographic distance ${ }^{14}$. In their view, these findings have to do with the fact that knowledge plays a greater role in cross-border $\mathrm{R} \& \mathrm{D}$, and this implies that cultural and social barriers may have a stronger impact than spatial separation in this case.

Dachs, Leitner and Stehrer (2012), show that geographic distance still holds a pivotal role in inhibiting $R \& D$ expenditures of foreign-owned subsidiaries in the manufacturing sector in a set of OECD countries. This finding does not contradict the observation that geographic distance plays a minor role in the case of greenfield R\&D FDIs. Indeed, Dachs et al.'s focus is on investment decisions undertaken by affiliates that are in place already. Rather than explaining the decision to offshore $R \& D$, their study highlights the complexities of managing R\&D networks abroad once they are set up, and help us understand the reasons why R\&D investments are a rare phenomenon, that is occurring at a slower pace and a lower intensity than the development of international production networks.

\section{Conclusions: In search for an analytical model}

The sparse evidence we have reviewed has highlighted that all three aspects of heterogeneity which we have examined - i.e. across regions, across firms and across functions - do matter when considering the role of distance factors on location decisions. We have shown that there are theoretical reasons to further investigate the heterogeneous impact of distance. A number of scholars have indeed addressed individual aspects of this heterogeneity. Showing that all three dimensions matter and have received some attention in extant studies is just the starting point for a reflection on how these dimensions should be treated and combined in interpretive and empirical models. Going much further in this reflection is by and large beyond the scope of this paper. However, at this stage we can put forward some considerations on some building blocks that could be addressed in order to proceed in this direction, and which we consider promising and relevant for international business, international trade and economic geography literature.

First, there is not in principle any reason to consider one of these dimensions more significant than the others: their relative importance is likely to depend on the research questions to be addressed. For instance, capturing the different impact of distance factors across functions/activities can be expected to be particularly relevant to explore patterns of international fragmentation of production and vertical FDI flows, more than horizontal ones. Analyzing distance across regions is most substantial when dealing with bilateral FDI flows involving large and

\footnotetext{
${ }^{14}$ They consider as institutional commonalities sharing colonial ties and legal origin (same legal system) as well as being part of the same regional trade agreement, or having signed a bilateral investment treaty. They also consider, as measures of institutional distance, cultural and social differences, proxied using differences in language and religion.
} 
institutionally variegated home and destination countries, and is less the case when dealing with small and relatively homogenous countries.

Second, there are interdependencies between these levels of heterogeneity. This might help understand why combining all levels, or at least more than one level, is worthwhile from an analytical point of view. Examining distance across firms might usefully complement the analysis of distance between regions. As exemplified in section 3 of this paper, for any given distance between home and host regions, location decisions are significantly facilitated if the investing firms already have established nodes of their (internal and/or) external networks in the destination region, or in a close-by location. In a similar vein, distance factors might well affect the location of a firm's activities/functions in a different way if agglomeration processes have taken place, as opposed to investment decisions that are taken in the open field, as a first move in that region. Using our terminology, this would envisage an interaction between heterogeneity across functions and heterogeneity across regions. To illustrate, some studies have reported evidence that location decisions of a new manufacturing plant is likely to be more affected by geographic distance than a new R\&D lab. However, the negative effect of geographic distance in the case of a manufacturing plant, might be moderated by the fact that in the destination region has already attracted other (local and foreign) investments, generating agglomeration economies. Agglomeration economies might more than compensate the costs of distance, especially when previous investments have taken place in upstream or downstream sectors. In other words: agglomeration economies can significantly reduce the (economic) distance between home and destination regions, and compensate the costs of geographic distance that are particularly high in the case of manufacturing plants.

Third, the consideration of the three aspects of heterogeneity discussed in this paper poses serious empirical problems. Reliable, longitudinal data allowing to measure both bilateral FDIs and distance factors are available at the national level from various established sources (see Dow and Kuranaratna 2006, Berry et al. 2010). Different combinations of data-sources can be used to obtain proxies of both bilateral FDIs and distance factors at the regional level. However, when one moves from the national to the sub-national level, it is not always clear what the appropriate unit of analysis should be. Goerzen at al. (2013) observe that the relevant unit of analysis when dealing with FDI decisions might well range from official city boundaries, to the inner city and the metropolitan area used, or to the "whole economic space of the surrounding region" (Goerzen at al. 2013, p.436). Moreover, sub-national data may pose some comparability problems. Countries are divided in a wide range of different sub-national units and it is often difficult to compare them across countries because they are referred to different extensions and spatial standards ${ }^{15}$. This most often implies restricting analyses to geographic areas for which common aggregation standards are used in official statistics ${ }^{16}$. Studies that analyse the role of distance in investment location decisions at the sub-national level most frequently consider relatively limited geographic areas, as in the case of subsets of the EU (Basile et al., 2008; Casi and Resmini, 2010). Several studies focus on intranational investment as in the case of location decisions across states within the US, or across Chinese provinces (Blanc-Brude et al., 2014; Chen, 2011; Sethi, Judge and Sun, 2011), Vietnamese provinces (Hoang and Goujon, 2014) and Russian regions (Ledyaeva, 2009).

\footnotetext{
${ }^{15}$ In the EU, this task is somewhat facilitated by the NUTS classification, and analysis of MNEs location choices have been conducted at the NUTS 2 or NUTS 3 level. However, it should be stressed that, for example, that NUTS 2 for UK and Germany include relatively smaller regions, than for the rest of Europe (e.g. Inner London, Greater Manchester, Berlin, vs. Andalusia, Lombardia or Bretagne). If one takes the OECD territorial levels (TL) faces an even bigger comparison problem, since TL2 includes US States (such as California, Texas or New York, which are as big as the average EU country) and NUTS 2 regions, as small as Inner London or Ile de France.

${ }^{16}$ FDI data at the regional level are not fully consistent even when analyses are restricted to European countries: "Only few studies have appeared recently with a regional focus, but most of them refer to small groups of European regions, often belonging to the same country or to a small groups of neighbouring countries, due to lack of data at the subnational level" (Casi and Resmini, 2010, p.100).
} 
Longitudinal firm level data on international production activities are also increasingly available for relatively large numbers of countries, although they are not equally reliable for all firm-size classes, countries of origin and destination (see Castellani and Zanfei 2006 for examples of integration of large firm level databases used for cross-country comparisons of FDI data). Most of these sources do offer some possibilities to detail data at the regional, sectorial and, less frequently, at the functional level. As a general rule, the more detailed you get at the regional, firm and functional levels, the lower the number of observations and the less comparable data appear to be.

To the best of our knowledge there are no quantitative studies combining all the three levels of heterogeneity identified in this paper, and indeed there are very few examples of works jointly considering more than one such levels. Casi and Resmini (2010) study the determinants of FDIs at regional level, distinguishing between manufacturing and service sectors (the latter can be considered as a rough measure of heterogeneity across firms). They test if variables often used to explain FDIs at the national-level, including distance, are also able to influence the location of investments at the regional-level (heterogeneity across regions). As recalled in a previous section, De Beule et al (2013) examine how the combination of two characteristics of investing firms, i.e. their national origin and their previous experience of host markets, help moderating the role of distance in entry mode strategies of multinationals in Italy. Castellani et al. (2013) analyse the impact of distance factors on location decisions, and control for both firm characteristics and for the nature of business activities in which FDIs are undertaken. They thus combine two levels of heterogeneity (across firms and across functions), and find that geographic distance matters in the case of manufacturing and not in the case of R\&D FDIs, but do not test whether the effect of distance differ also by type of firm.

A possible way to deal with data limitations constraining quantitative analyses could be to resort to more exploratory, case-history based studies. Of course, case studies allow much less conclusive inference, and insights deriving from them can hardly be generalised. Nevertheless, they can provide important indications concerning weak signals of change and causal links that could not be detected by analysing general trends and average values. A comprehensive understanding of the role of distance factors across different regions, firms and functions thus calls for a combination of analytical techniques. These include quantitative analyses based on the integration (and often construction) of extensive datasets, and qualitative case studies to explore the emergence of largely unexplored phenomena. 


\section{References}

Abdi M. and Aulakh P.S. 2012. Do country-level institutional frameworks and interfirm governance arrangements substitute or complement in international business relationships? Journal of International Business Studies (2012) 43, 477-497.

Ambos, B., and Ambos, T.C. 2011. Meeting the challenge of offshoring R\&D: an examination of firm- and location-specific factors. R\&D Management, 41(2): 107-119.

Anderson, J.E., van Wincoop, E., 2003. Gravity with Gravitas: A Solution to the Border Puzzle. American Economic Reviewj 93, pp. 170-192.

Appold, S.J. 1995. Agglomeration, Interorganizational Networks, and Competitive Performance in the U.S. Metalworking Sector, Economic Geography, 71(1): 27-54.

Athukorala P.C. and Kohpaiboon A. 2006. "Multinational enterprises and Globalization of R\&D: A Study of U.S-based Firms", Australian National University, Economics RSPAS Departmental working Papers 2006-06.

Basile R., Benfratello L. and Castellani D. 2006. Attracting Foreign Direct Investments in Europe: Are Italian Regions Doomed? In Malgarini M. and Piga G. (Eds.) Capital Accumulation, Productivity and Growth. Monitoring Italy 2005, pp. 319-354. Houndmills, Basingstoke and New York: Palgrave Macmillan.

Basile, R., Castellani, D. and Zanfei, A. 2008. Location choices of multinational firms in Europe: the role of EU cohesion policy. Journal of International Economics, 74: 328-340.

Beckerman, W. 1956. Distance and the pattern of intra-European Trade. Review of Economics and Statistics, 28: 31-40.

Belderbos R., Leten B., and Suzuki, S. 2011. "Academic Research, Firm Heterogeneity and Foreign R\&D Locations of Multinational Firms". Paper presented at the 2011 DRUID Conference.

Benner, M., and Waldfogel, J. 2008. Close to you? Bias and precision in patent-based measures of technological proximity. Research Policy, 37(9), 1556-1567.

Bergstrand, J.H., and Egger, P. 2007. A knowledge-and-physical-capital model of international trade flows, foreign direct investment, and multinational enterprises. Journal of International Economics, 73(2): 278-308.

Berry, H., Guillen, M., and Zhou, N. 2010. An institutional approach to cross-national distance. Journal of International Business Studies, 41: 1460-1480.

Beugelsdjik, S., McCann, P. and Mudambi, R. 2010. Introduction: Place, space and organizationeconomic geography and the multinational enterprise. Journal of Economic Geography (2010) 10 (4): 485-493.

Blanc-Brude, F., Cookson, G., Piesse, J., and Strange, R. 2014. The FDI location decision: Distance and the effects of spatial dependence. International Business Review.

Blonigen, B.A., Davies, R.B., and Head, K. 2003. Estimating the Knowledge-Capital model of the multinational enterprise: Comment. American Economic Review, 93(3): 980-994.

Boschma, R.A. 2005. Proximity and innovation: a critical assessment. Regional studies, 39(1), 6174.

Broekel, T., and Boschma, R.A. 2012. Knowledge networks in the Dutch aviation industry: the proximity paradox. Journal of Economic Geography, 12(2), 409-433. 
Breschi, S., and Lissoni, F. 2003. "Mobility and social networks: Localised knowledge spillovers revisited”. Milan: University Bocconi, CESPRI Working Paper, (142).

Bronzini R. 2007. FDI inflows, agglomeration and host country firms' size: evidence from Italy. Regional Studies 41, 963-978.

Burt, R.S. 2000. The network structure of social capital. Research in organizational behavior, 22, 345-423.

Cantwell J.A. and Piscitello L. 2005. Recent Location of Foreign-owned Research and Development Activities by Large Multinational Corporations in the European Regions: The Role of Spillovers and Externalities, Regional Studies 39(1), 1-16.

Carr, D.L., Markusen, J.R., and Maskus, K.E. 2001. Estimating the Knowledge-Capital model of the multinational enterprise. American Economic Review, 91(3): 693-708.

Casella, A., and Rauch, J.E. 2003. Overcoming informational barriers to international resource allocation: Prices and ties. The Economic Journal, 113(1): 21-42.

Casi, L., Resmini, L. 2010. Evidence on the determinants of foreign direct investment: the case of EU regions. Eastern Journal of European Studies, vol.1(2), pp.93-117, December.

Castellani, D., Jimenez, A., and Zanfei, A. 2013. "How remote are R\&D labs? Distance factors and international innovative activities". Journal of International Business Studies, Volume 44, Number 7, 5 September 2013, pp. 649-675(27).

Castellani, D., and Zanfei, A. 2006. Multinational firms. Innovation and Productivity. Edward Elgar.

Castellani, D. and Zanfei, A. 2004. Choosing international linkage strategies in the electronics industry: the role of multinational experience. Journal of Economic Behavior \& Organization, Volume 53, Issue 4, April 2004, Pages 447-475.

Chen, C. 2011. Provincial characteristics and the FDI location decision within China, in Foreign direct investment in China. Location determinants, investor differences, and economic impacts (pp. 132-51). Elgar Publishing Limited, UK.

Chen, H. and Chen, T.-J. 1998. Network Linkages and Location Choice in Foreign Direct Investment. Journal of International Business Studies, Vol. 29 Issue 3, pp. 445-467.

Clarke, J.E., Tamaschke, R., and Liesch, P.W. 2013. International experience in international business research: A conceptualization and exploration of key themes. International Journal of Management Reviews, Vol. 15, pp. 265-279.

Coughlin, C.C. and Novy, D. 2011. "Is the International Border Effect Larger than the Domestic Border Effect? Evidence from U.S. Trade", mimeo

Crescenzi, R., Pietrobelli C. and Rabellotti R. 2012. "Innovation Drivers, Value Chains and the Geography of Multinational Firms in European Regions”. LEQS Paper n. 53/2012. Electronic copy available at: $\underline{\text { http://ssrn.com/abstract }=2175836}$

Crozet M., Mayer T. and Mucchielli J.J. 2004. How do firms agglomerate? A study of FDI in France, Regional Science and Urban Economics 34, 27-54.

Dachs, B., Leitner, S.M. and Stehrer, R. 2012. "The Gravity of Cross-border R\&D Expenditure (No. 91)". The Vienna Institute for International Economic Studies.

Dachs, B., and Pyka, A. 2010. What drives the internationalisation of innovation? Evidence from European patent data. Economics of Innovation and New Technology, 19(1): 71-86. 
De Beule, F., Elia, S. and Piscitello, L. 2013. Entry and access to competencies abroad: Emerging market firms versus advanced market firms. Journal of International Management (2013), http://dx.doi.org/10.1016/j.intman.2013.05.002.

Defever F. 2012. The Spatial Organization of Multinational Firms, Canadian Journal of Economics, 2012, $\mathrm{Vol} 45, \mathrm{~N}^{\circ} 2$

Defever F. 2008. Is it strategic to attract the service activities of multinational firms? Some empirical evidence, in Brakamn S. and Garretsen H. (Eds) Foreign Direct Investment and the Multinational Enterprise. MIT Press.

Defever, F. 2006. Functional fragmentation and the location of multinational firms in the enlarged Europe. Regional Science and Urban Economics, 36(5), 658-677.

Demirbag, M. and Glaister, K.W. 2010. Factors Determining Offshore Location Choice for R\&D Projects: A Comparative Study of Developed and Emerging Regions. Journal of Management Studies, 47: 1534-1559.

Dimitropoulou, D., McCann, P. and Burke, S.P. 2013. The determinants of the location of foreign direct investment in UK regions. Applied Economics, 2013, vol. 45, issue 27, pp. 3853-3862.

Dow, D. and Ferencikova, S. 2010. More than just national cultural distance: Testing new distance scales on FDI in Slovakia. International Business Review, 19(1): 46-58.

Dow, D. and Karunaratna, A. 2006. Developing a Multidimensional Instrument to Measure Psychic Distance Stimuli. Journal of International Business Studies, 37.5 (2006): 578-602.

Dow, D. and Larimo, J. 2009. Challenging the Conceptualization and Measurement of Distance and International Experience in Entry Mode Choice Research. Journal of International Marketing, 17(2): 74-98.

Dow, D. and Larimo, J. 2011. Disentangling the Roles of International Experience and Distance in Establishment Mode Choice. Management International Review, 51(3): 321-355.

Dunning, J.H. 1970, Studies in International Investment, George Allen \& Unwin, London.

Dunning, J.H. 2009. Location and the multinational enterprise: John Dunning's thoughts on receiving the Journal of International Business Studies 2008 Decade Award. Journal of International Business Studies, 40(1): 20-34.

Dunning, J.H. 1977. "Trade, Location of Economic Activity and the MNE: A Search for an Eclectic Approach.” In Bertil Ohlin, Per-Ove Hesselborn, and Per Magnus Wijkman, eds., The International Allocation of Economic Activity. London: Macmillan.

Dunning, J.H. and Lundan, S.M. 2009. The Internationalization of Corporate R\&D: A Review of the Evidence and Some Policy Implications for Home Countries. Review of Policy Research, 26(12): 13-33.

Egger, P. and Pfaffermayr, M. 2004. The impact of bilateral investment treaties on foreign direct investment. Journal of Comparative Economics, 32: 788-804.

Ellis, P. 2008. Does psychic distance moderate the market size-entry sequence relationship?. Journal of International Business Studies, 39(3): 351-369.

Em, L. 2011. "Disentangling the different concepts of distance: a lexicographic exploration of the past 20 years of the Journal of International Business Studies". The Selected Works of Laetitia EM, Mimeo.

Geraci, V. J., and Prewo, W. 1977. Bilateral trade flows and transport costs. The Review of Economics and Statistics, 67-74. 
Goerzen, A., Asmussen C.G. and Nielsen, B.B. 2013. Global cities and multinational enterprise location strategy. Journal of International Business Studies (2013) 44, 427-450.

Granovetter, M. 1985. Economic action and social structure: the problem of embeddedness. American journal of sociology, 481-510.

Grossman, G. 1996. "Comments on Alan V. Deardorff, "Determinants of bilateral trade: Does gravity work in a neoclassical world?". In The regionalization of the world economy. Jeffrey A. Frankel, ed., Chicago: University of Chicago for NBER.

Guiso, L., Sapienza, P., and Zingales, L. 2009. Cultural biases in economic exchange? Quarterly Journal of Economics, 124(3): 1095-1131

Håkanson, L., and Ambos, B. 2010. The antecedents of psychic distance. Journal of International Management, 16: 195-210.

Halvorsen T. 2012. Size, Location and Agglomeration of Inward Foreign Direct Investment (FDI) in the United States. Regional Studies 46(5), 669-682.

Head, K. and Mayer, T. 2009. Illusory Border Effects: Distance Mismeasurement Inflates Estimates of Home Bias in Trade. In: The Gravity Model in International Trade: Advances and Applications. Editors: Bergeijk and Brakman, Cambridge University Press.

Head K. and Mayer T. 2004. Market Potential and the Location of Japanese Investment in the European Union, The Review of Economics and Statistics 86(4), 959-972.

Head, K., Mayer, T. and Ries, J. 2009. How remote is the offshoring threat. European Economic Review, 53: 429-444.

Head K., Ries J. and Swenson D. 1999. Attracting foreign manufacturing: Investment promotion and agglomeration. Regional Science and Urban Economics 29(2), 197-218.

Helpman, Elhanan, Melitz, Marc J. and Yeaple, Stephen R. 2004. Export versus FDI with Hetrogeneous Firms, American Economic Review, 94, 300-316.

Hennart, J.-F. and Park, Y.R. 1994. "Location, governance and strategic determinants of Japanese manufacturing investment in the United States". Open Access publications from Tilburg University urn:nbn:nl:ui:12-174010, Tilburg University.

Heskett, J.L., and Kotter, J.P. 1992. Corporate culture and performance. Business Review, Vol, 2, 83-93.

Hilber C. and Voicu I. 2010. Agglomeration Economies and the Location of Foreign Direct Investment: Empirical Evidence from Romania, Regional Studies 44(3), 355-371.

Hillberry, R., Hummels, D. 2003. Intranational Home Bias: Some Explanations. Review of Economics and Statistics, 85, pp. 1089-1092.

Hillberry, R., Hummels, D. 2008. Trade Responses to Geographic Frictions: A Decomposition Using Micro-Data. European Economic Review, 52, pp. 527-550.

Hoang, H. H., and Goujon, M. 2014. Determinants of foreign direct investment in Vietnamese provinces: a spatial econometric analysis. Post-Communist Economies, 26(1), 103-121.

Hofstede, G. 1980. Cultural Consequences: International Differences in Work Related Values. Beverly Hills: Sage Publications.

Huang, R. R. 2007. Distance and trade: Disentangling unfamiliarity effects and transport cost effects, European Economic Review, Vol. 51, Issue 1, January 2007, Pages 161-181. 
Hutzschenreuter, T., Voll, J.C. and Verbeke, A. 2011. The Impact of Added Cultural Distance and Cultural Diversity on International Expansion Patterns: A Penrosean Perspective. Journal of Management Studies, Volume 48, Issue 2, pages 305-329, March 2011.

Hymer, S. H. 1960. 'The international operations of national firms: A study of direct foreign investment' Ph.D. dissertation, Massachusetts Institute of Technology (published by MIT Press, 1976).

Iammarino, S. and McCann, P. 2013. Multinationals and economic geography: location, technology and innovation. Edward Elgar, Cheltenam, UK.

Ietto-Gillies, G. 2001. Transnational Corporations: Fragmentation Amidst Integration (London: Routledge).

Johanson, J. and Vahlne, J.E. 1977. The Internationalization Process of the Firm-A Model of Knowledge Development and Increasing Foreign Commitments. Journal of International Business Studies, 8(1): 23-32.

Johanson, J. and Vahlne, J.E. 1990. The Mechanism of Internationalisation. International Marketing Review, 7 (4): 11.

Johanson, J. and Vahlne, J.E. 2009. The Uppsala internationalization process model revisited: From liability of foreignness to liability of outsidership. Journal of International Business Studies, 40: 1411-1431.

Kleinert, J. and Toubal, F. 2010. Gravity for FDI. Review of International Economics, 18(1): 1-13.

Kogut, B. and Singh, H. 1988. The Effect of National Culture on the Choice of Entry Mode. Journal of International Business Studies, 19(3): 411-432.

Ledyaeva, S., 2009. Spatial econometric analysis of foreign direct investment determinants in Russian regions. The World Economy, 32 (4), 643-666

Lewin, A.Y., Massini, S. and Peeters, C. 2009. 'Why are companies offshoring innovation? The emerging global race for talent'. Journal of International Business Studies, 40, 901-25.

Linneman, Hans. 1966. An econometric study of international trade flows. Amsterdam: NorthHolland.

Mariotti, S. and Piscitello, L. 1995. "Information costs and location of FDIs within the host country: empirical evidence from Italy”, International Journal of Business Studies, 26 849, pp. 815-841.

Maskell, P., and Malmberg, A. 1999. Localised learning and industrial competitiveness. Cambridge Journal of Economics, 23(2), 167-185.

McCallum, J. 1995. National borders matter: Canada-US regional trade patterns. The American Economic Review, 85(3), 615-623.

Meyer, K.E. and Nguyen, H.V. 2005. "Foreign Investment Strategies and Sub-national Institutions in Emerging Markets: Evidence from Vietnam", Journal of Management Studies 42, no. 1, p. 6393.

Mudambi, R. and Beugelsdijk, S. 2013. MNEs as border-crossing multi-location enterprises: The role of discontinuities in geographic space. Journal of International Business Studies (2013) 44, $413-426$.

Mudambi, R. and Navarra, P. 2003. Political Tradition, Political Risk and Foreign Direct Investment in Italy. Management International Review, vol.43(3), pp.247-265, 2003. 
Muralidharan, R., and Phatak, A. 1999. International R\&D Activity of US MNCS: An Empirical Study with Implications for Host Government Policy. Multinational Business Review 7(2), 97-105.

Nachum L. 2000. Economic geography and the location of MNEs: Financial and professional service FDI to the US. Journal of International Business Studies, 31(3): 367-386.

OECD 2011. Attractiveness for Innovation: Location Factors for International Investment, OECD, Paris.

Oerlemans, L.A.G. and Meeus, M.T.H. 2005. Do Organizational and Spatial Proximity Impact on Firm Performance?. Regional Studies, Vol. 39.1, pp. 89-104, February 2005

Pelegrin, A. and Bolancé, C. 2008 Regional Foreign Direct Investment in Manufacturing. Do Agglomeration Economies Matter? Regional Studies 42:(4), 505-522.

Picci, L. 2010. The internationalization of inventive activity: A gravity model using patent data. Research Policy, 39 (2010), pp. 1070-1081.

Py, L., and Hatem, F. 2009. Where Do Multinationals Locate Manufacturing and Service Activities in Europe and Why?. Economie et Statistique, 426: 67-95.

Rugman, A.M., Verbeke, A. and Nguyen, Q.T.K. 2011. Fifty Years of International Business Theory and Beyond. Management International Review, December 2011, 51 (6): 755-786.

Sethi, D., Judge, W.Q., and Sun, Q. 2011. FDI distribution within China: An integrative conceptual framework for analyzing intra-country FDI variations. Asia Pacific Journal of Management, 28(2), 325-352.

Shenkar, O. 2001. Cultural Distance Revisited: Towards a More Rigorous Conceptualization and Measurement of Cultural Differences. Journal of International Business Studies, 32 (3): 519-536.

Singh, J. and Marx, M. 2013. Geographic Constraints on Knowledge Spillovers. Management Science, 59(9), pp. 2056-2078.

Solomon, R. and $\mathrm{Wu}, \mathrm{Z} .2012$. Institutional distance and local isomorphism strategy. Journal of International Business Studies, (2012) 43, 343-367.

Smith, M., Dowling, P.J. and Rose, E.L. 2011. Psychic distance revisited: A proposed conceptual framework and research agenda. Journal of Management \& Organization (2011) 17: 123-143.

Stottinger, B. and Schlegelmilch, B.B. 1998. Explaining export development through psychic distance: enlightening or elusive?. International Marketing Review, 15(5): 357-372.

Tinbergen, J. 1962. The World Economy. Suggestions for an International Economic Policy, New York: Twentieth Century Fund.

Trefler, D. 2005. Service offshoring: threats and opportunities, Brookings Trade Forum on "The Offshoring of Services: Issues and Implications", Washington D.C., May 12-13, 2005.

Tung, R.L., and Verbeke, A., 2010."Beyond Hofstede and GLOBE: Improving the quality of cross cultural research. Journal of International Business Studies, 41, 1259-1274.

von Zedwitz, M., and Gassmann, O. 2002. Market versus technology drive in R\&D internationalization: four different patterns of managing research and development. Research Policy, Vol. 31, pp. 569-588.

UNCTAD, 2006. World Investment Report, FDI from Developing and Transition Economies: Implications for Development, Geneve, UNCTAD.

Xu, D., Pan, Y., and Beamish, P. 2004. The effect of regulative and normative distances on MNE ownership and expatriate strategies. Management International Review, 44(3), 285-307. 
$\mathrm{Xu}, \mathrm{D}$. and Shenkar, D. 2002. Institutional Distance and the Multinational Enterprise, The Academy of Management Review, Vol. 27, No. 4 (Oct., 2002), pp. 608-618.

Yeaple, S., 2009. Firm heterogeneity and the structure of U.S. multinational activity: an empirical analysis. Journal of International Economics 78 (2), 206-215.

Yeoh, P.L. 2004. International learning: antecedents and performance implications among newly internationalizing companies in an exporting context. International Marketing Review, 21(4/5), 511-535.

Wolf, H. 2000. Intranational Home Bias in Trade. Review of Economics and Statistics, 82, pp. 555563.

Zaheer, S. 1995. Overcoming the Liability of Foreignness. The Academy of Management Journal, Vol. 38, No. 2 (Apr., 1995), pp. 341-363.

Zanfei, A. 2000. Transnational Firms and the Changing Organisation of Innovative Activities, Cambridge Journal of Economics, Oxford University Press, vol. 24(5), pages 515-42, September. 